\title{
Understanding regional economic performance and resilience in the UK: trends since the Global Financial Crisis
}

\author{
Dr Marianne Sensier, Research Fellow, Economics \\ and \\ Professor Fiona Devine, Alliance Manchester Business School \\ University of Manchester
}

February 2020

\begin{abstract}
We investigate economic resilience of UK regions before, during and after the 2007/08 global financial crisis. We date business cycle turning points in real GVA, employment and productivity to assess the resilience dimensions of resistance, recovery and renewal and rank the economic resilience of regions in a resilience scorecard. Our empirical results reveal that the business cycle in productivity has not returned to its pre-recession peak level for Yorkshire and Humberside and the employment level has not recovered in Scotland. The resilience scorecard ranks the South East as the most resilient region with Northern Ireland the least resilient.
\end{abstract}

Keywords: economic resilience, regional disparities, productivity, business cycles.

JEL classification: C22, E32 


\section{Introduction}

The headline figures for the UK national economy masks huge regional disparities and the gap is growing between London and other UK regions and countries. The UK has the greatest spatial disparity among European countries in terms of GDP per head (see Wong et al, 2019). The Industrial Strategy Commission (2017) stated that this extraordinary regional imbalance is "now a major drag on the performance of the whole UK economy, with deleterious effects on productivity and fiscal balance", (p.87). These disparities have widened since the global financial crisis, with some regions demonstrating greater economic resilience while others have been slow to recover. The UK economy has also suffered from a "productivity puzzle" of very low growth in national productivity since before the financial crisis, see McCann (2018). Many explanations have been put forward for the low growth in productivity including the stalling of investment and innovation (Sichel, 2019), digital and communication technologies being undercounted in the UK accounts (Coyle, 2018) and the rise in low paid and insecure work (Forth and Aznar, 2018). Our contribution to the literature is to assess regional disparities and analyse the economic resilience of UK regions over the course of the financial crisis in terms of their output, employment and labour productivity. We apply a business cycle dating algorithm to retrieve individual turning points for the regional time series between 1998-2018. Based on our set of resilience measures for resistance, recovery and renewal we create a resilience scorecard to rank the UK region's resilience at the NUTS 1 level.

To preview our results, our empirical work reveals that real productivity has returned to its pre-recession peak level for all but one NUTS 1 region (Yorkshire and Humberside) and the employment level has not yet recovered in Scotland (with data up to 2018). All UK region's real GVA series have returned to their pre-recession levels but rapid job growth in many regions (apart from the North East and Scotland) has reduced productivity growth rates with only the Midlands and Northern Ireland experiencing higher rates after the recession. According to our resilience scorecard the South East is the most resilient region with Northern Ireland the least resilient. The resilience scorecard could be a useful tool for policy makers in local and central Government to help identify the least resilient regions that have struggled since the financial crisis and are in need of greater resources in order to "level up" productivity rates with the rest of the UK. The structure of the paper is as follows: in the next section we review the literature on economic resilience; in section 3 we describe our business cycle dating methodology, data and the statistical measures used to calculate the resilience scorecard; in section 4 we report the empirical results including regional disparities and the resilience scorecard and conclude in section 5. 


\section{Economic Resilience}

Regional economic resilience is defined as the capacity of a regional economy to withstand, recover from and reorganise in the face of market, competitive and environmental shocks to its developmental growth path (Bristow and Healy, 2014; Martin and Sunley, 2015). The root cause of these shocks could be global (the 2008 financial crisis), national (1990s house price crash) or local (closing of a factory) in nature. Martin (2012) analysed the resilience of UK regions and defines four dimensions of economic resilience to describe how a regional economy responds to a recessionary shock. The first dimension is resistance which is the sensitivity of a region compared to the nation during the recession. The second is the speed and extent of the recovery from the recession. The third is assessing if the region has undergone structural re-orientation and what implications this has for the region's jobs, output and income. The fourth is the degree of renewal a region will undergo following the shock and the extent to which it renews its growth path.

A number of empirical studies have examined UK regional resilience. Martin and Gardiner (2019) chart 85 UK cities economic resilience over three recessions and four decades and they forecast how city regions could respond to a Brexit shock. They discover that northern cities have lower recoverability rates from recession than southern cities and that generally city recoverability has declined with distance from London. Kitsos and Bishop (2018), study local authorities employment rates in Great Britain and estimate cross-section regressions where the dependent variable is the impact of the recession on the employment rate. They find that areas with higher initial employment rates experienced greater falls in employment over the downturn and that this impact was greater for the North of England and West Midlands. They also found that those areas with a greater share of higher level skills and younger populations had less employment declines and were more resilient. Lee (2014) found that UK cities with higher skill levels had the smallest increase in unemployment over the 2008-09 recession. Martin et al (2016) state that economic structure of places varies across the UK and the degree of foreign ownership, the geographical distribution of supply chains, export orientation and legacy of the inherited labour market all play a part in why some regions are more resilient than others. Bailey and Berkeley (2014) discuss the operation of the West Midland's Regional Taskforce that was set up to deal with business and employment issues during the downturn to ensure resilience over the short and longer term. They document a number of central and local government funds that were set up to help firms access credit and advice during the downturn. The retention of institutional memory and lessons from dealing with the 2005 closure of the Rover plant were vital in helping deal with 2008 recession. They suggest the resilience dimensions of resistance and recovery were important in the short-term but then the renewal and reorientation of the local automotive sector to diversify into low carbon and higher value activities were crucial for long-term planning. 
A European Commission project, Resil.net, has produced a dashboard of indicators for European countries and regions resilience. Manca et al (2017) propose a framework for societal resilience and suggest a society can resist shocks (absorptive capacity); adopt a degree of flexibility in making changes (adaptive capacity) and may need larger system change (transformative capacity). Pontarollo and Serpieri (2018) analyse the life cycle of resilience for European NUTS 2 level regions utilising stages of the cycle to create a regional economic resilience indicator. Studies that have examined the resilience of US counties include Han and Goetz (2015) who find that counties employment level that entered recession earlier had longer downturns and that those adjacent to metro areas experienced more serious shocks. Ringwood et al (2019) measure resilience of US counties over the 2007-09 shock and find that farming dependent counties in rural locations were the most resilient compared to those reliant on manufacturing. Lewin et al (2017) analyse US counties personal income and find that counties with increased income inequality entered recession earlier, they suggest this could be due to falling personal savings and increased credit in the run up to the financial crisis.

In contrast to previous studies that largely rely on the onset of the recession to be the same time period for each region within a country our research individually dates business cycle turning points for regions. In Sensier et al (2016) we analyse the effect of the global financial crisis on regions across Europe. GDP and employment are compared as the reference state for European NUTS 2 regions and a business cycle dating algorithm is then applied to individual regions to allow flexibility so regions can have different turning points (peaks and troughs) in their economic cycle. This allows for some regions to lead and some to lag the movements in their national business cycle. This approach enabled us to assess if each region's GDP and employment were resistant to the crisis or if they experienced recession, we were then able to quantify the duration and depth of the downturn in economic variables to map the progress and the impact of the crisis across Europe. An additional contribution of our study is the introduction of an economic resilience scorecard which allows us to rank places based on their resilience measures of resistance, recovery and renewal compared to the national average before, during and after the financial crisis. This gives a fuller picture of the evolution of regional growth paths before and after the crisis.

\section{Business Cycle and Resilience Methodology}

Our approach builds on Sensier and Artis (2016) which dates countries within the UK employment cycles, and adds flexibility to the approach of Martin (2012). The economy can be in either of two mutually exclusive phases: expansion phase $\left(E_{t}\right)$ or recession phase $\left(R_{t}\right)$. The convention is that a peak terminates an expansion and a trough terminates a recession. To enforce the alternation of peaks and troughs it is useful to distinguish turning points within these two phases: 


$$
\begin{aligned}
E_{t} & \equiv\left\{\begin{array}{l}
C E_{t} \\
P_{t}
\end{array}\right. \\
R_{t} & \equiv\left\{\begin{array}{l}
C R_{t} \\
T_{t}
\end{array}\right.
\end{aligned}
$$

From the continuation of expansion $\left(C E_{t}\right)$ we can make a transition to the peak $\left(P_{t}\right)$ or continue the expansion, but not vice versa as only $P_{t} \rightarrow C R_{t+1}$ is admissible. Analogously, from continuation of recession $\left(C R_{t}\right)$ we can make a transition to the trough $\left(T_{t}\right)$ and $T_{t} \rightarrow C E_{t+1}$ with the probability of 1 . The dating rules impose a minimum duration of a phase of 1 year as we are analysing annual data. We also impose the minimum length of the entire business cycle (from peak to peak) to be 3 years. The maximum length of cycle is unlimited and if two business cycle phases occur in quick succession then the maximum (highest peak) is dated as the start of the cycle and the minimum (lowest trough) is the end of the cycle, this could then take in two cycles (a 'double dip' recession). In the Empirical Results section we utilise the business cycle turning points dating algorithm in Stata 14 program adapted from Harding and Pagan (2002).

We assess how UK regions fared in the run up to the financial crisis, then during the recession and how they subsequently recovered. We compare UK regions at the NUTS 1 level and assess economic performance with the Office for National Statistics (ONS) time series of regional real balanced Gross Value Added (GVA) produced in 2016 pounds which takes account of regional price differences (see ONS, 2020). UK national GVA is the sum of the regions and countries and excludes Extra-Regio which is the activity that cannot be assigned to regions (this is to match the number of productivity jobs as the UK total is less Extra-Regio). The employment series is the amount of productivity jobs from the latest subregional productivity release ONS (2020). We calculate real productivity as:

Real Productivity $=$ Real GVA/Productivity Jobs

When we have established the turning points of the business cycle we can calculate a range of indicators that will be utilised in the resilience scorecard and in the cross-section regressions. We calculate the LOSS over the recession where we take the difference in the level of employment in a region $\left(E m r_{r}\right)$ between the peak and trough dates and divide this by the level at the peak, multiplying by 100 to show a percentage loss:

LOSS $=100 .\left(E m p_{\text {peak }} r-E m p_{\text {trough_r }}\right) / E m p_{\text {peak }}$ r $]$

The duration of the recession is the difference in years between the trough and peak dates.

To compare the resistance of regions to the nation we compute a sensitivity index $\left(B_{r}\right)$ from Martin (2012) which is the percentage change in the variable, here for employment lost in a region $\left(E m p_{r}\right)$ compared to that lost at the national level $\left(E m p_{n}\right)$, between peaks and trough turning points as follows: 
If the value of $B_{r}>1$ then the region has lost a greater percentage of employment than the nation and is less resistant to the recession but if the $b_{r}<1$ then the region has lost a smaller share of employment than the nation and is more resistant to the recession than the nation.

We calculate the expansion average growth rate (EAGR) to measure the 5 year average of the growth rate (first difference of the natural log) before the recession including the date of the peak year. Following the recession we calculate the rate of growth for the series after the trough by taking the second expansion average of the growth rate (E2AGR) for 5 years. To rank UK region's economic resilience we present a resilience scorecard that compares regional statistics before, during and after the recession to assess a region's growth path. The resistance of regions are compared to the nation as the benchmark along with how quickly they recovered from the crisis. The renewal measure compares the growth rates 5 years before the recession and then 5 years after the recession. A greater rate of increase after the recession indicates that the region is accelerating to a higher growth path. The date of recovery is noted when the region has regained its pre-recession peak level or if by 2018 (last year available) it has not recovered (NR). The economic resilience scorecard ranks the resilience measures for all UK regions. We will compare 4 statistics for each region over the recession and up to 2018, including:

1. RESISTANCE: Has the fall in GVA/jobs/productivity been less than the national decrease (so is the sensitivity index $b_{r}<1$ )?

2. DURATION: Has the duration of the recession been shorter or the same as the national recession?

3. RECOVERY: Has the region recovered faster or at the same time as the nation?

4. RENEWAL: Was the rate of growth after recession greater than before (E2AGR> EAGR)?

If the answer to the above question is yes then the region is classified as being more resilient than the national data series and is coded 1 , if no it is less resilient and coded 0 . Based on the binary response to these questions we sum up all regions over 4 statistics for 3 variables, so the highest score for a region if it has been very resilient is 12 .

\section{Regional Business Cycles: Data and Disparities}

In this section we compare the regional shares of national GVA and jobs and highlight regional disparities in productivity levels. In Table 1 the regional shares of real GVA are shown for three years: 1998, 2007 \& 2018, and then for productivity jobs for 1998, 2008 and 2018 (2007 is the most frequent peak date for GVA in Table 3 and 2008 the most frequent peak date for jobs in Table 4). The regional share of GVA for most regions has fallen between 1998 and 2018 with the exception of London which has grown from almost 20\% 
share of real GVA in 1998 to just under 24\% in 2018. The productivity jobs series have followed a similar pattern with London, the South West and the East of England increasing their share of total employment and the South East and Wales increasing up to 2008 but decreasing slightly by 2018 .

Table 1: Regional Shares of National Real GVA and Jobs (percentages of UK total)

\begin{tabular}{|l|c|c|c|c|c|c|}
\hline & \multicolumn{3}{|c|}{ Real GVA } & \multicolumn{3}{c|}{ Productivity Jobs } \\
\hline Region & $\mathbf{1 9 9 8}$ & $\mathbf{2 0 0 7}$ & $\mathbf{2 0 1 8}$ & $\mathbf{1 9 9 8}$ & $\mathbf{2 0 0 8}$ & $\mathbf{2 0 1 8}$ \\
\hline North East & 3.25 & 3.24 & 2.88 & 3.82 & 3.72 & 3.43 \\
\hline North West & 9.89 & 9.92 & 9.66 & 10.85 & 10.72 & 10.65 \\
\hline $\begin{array}{l}\text { Yorkshire and The } \\
\text { Humber }\end{array}$ & 7.15 & 7.21 & 6.51 & 8.13 & 7.97 & 7.85 \\
\hline East Midlands & 6.21 & 5.87 & 5.75 & 6.94 & 6.84 & 6.74 \\
\hline West Midlands & 8.05 & 7.27 & 7.46 & 8.96 & 8.45 & 8.39 \\
\hline East of England & 8.75 & 8.64 & 8.71 & 8.84 & 8.96 & 9.18 \\
\hline London & 19.69 & 22.02 & 23.89 & 14.84 & 15.35 & 16.93 \\
\hline South East & 15.26 & 14.7 & 14.65 & 13.89 & 13.92 & 13.81 \\
\hline South West & 7.72 & 7.41 & 7.37 & 8.40 & 8.47 & 8.51 \\
\hline Wales & 3.79 & 3.61 & 3.44 & 4.19 & 4.33 & 4.2 \\
\hline Scotland & 7.89 & 7.71 & 7.49 & 8.56 & 8.59 & 7.79 \\
\hline Northern Ireland & 2.35 & 2.39 & 2.19 & 2.58 & 2.68 & 2.52 \\
\hline
\end{tabular}

Figure 1: Difference between National and Regional Productivity over time

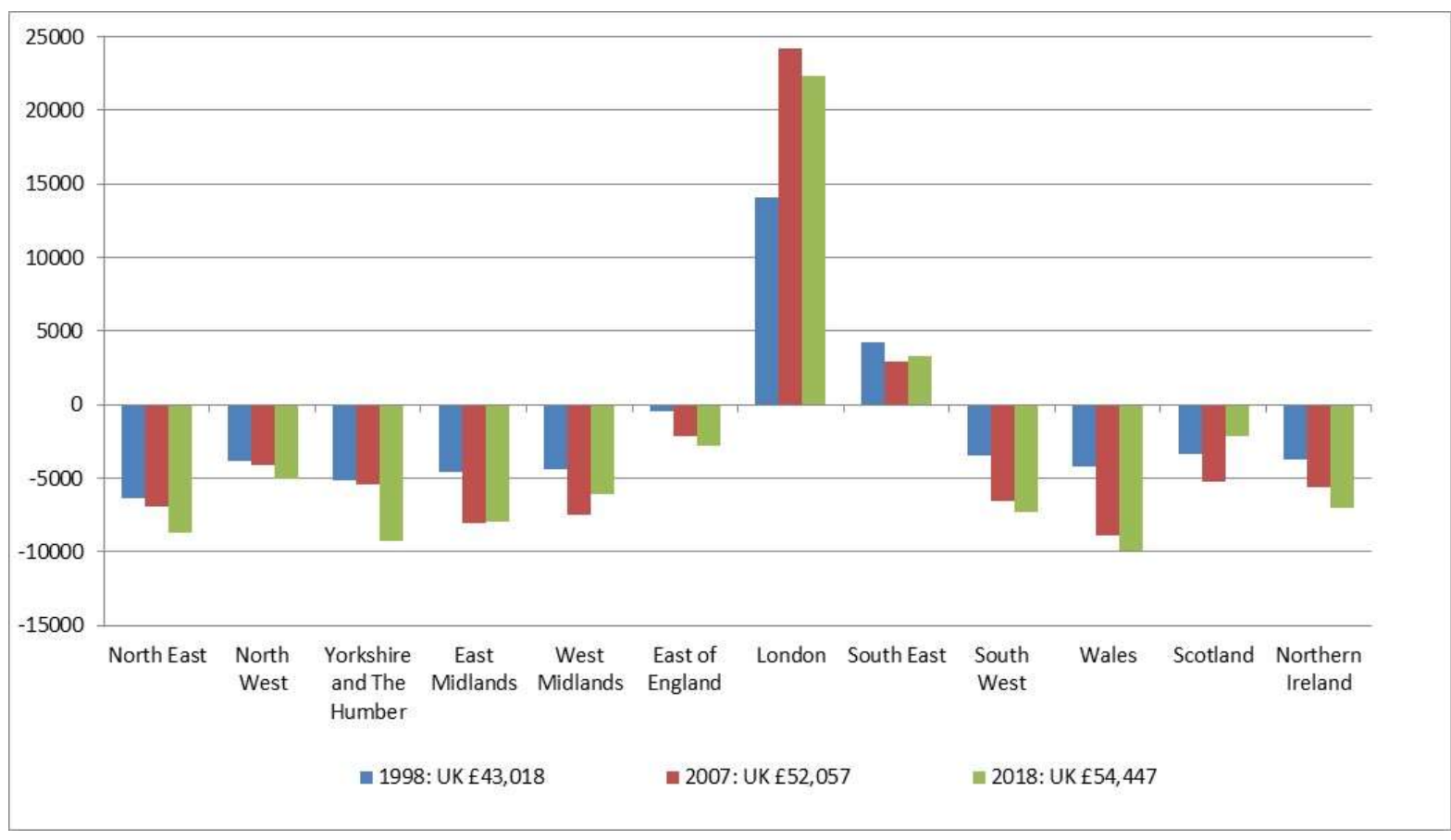


In terms of real productivity we compare the productivity gap between each region with the UK national productivity level (excluding extra regio) in Figure 1. The ONS estimates of real productivity per job filled in 2018 for the UK was $f 54,447$, with the highest region being London $(£ 76,795)$, middle of the range are the North West $(£ 49,416)$ and the West Midlands $(£ 48,397)$ and the lowest is Wales $(£ 44,496)$. From Figure 1 we can see that as the London share of output and employment has increased the productivity gap with the UK has widened with the largest gap in 2007 with London productivity per job filled $£ 24,243$ greater than UK productivity, falling slightly by 2018. The negative gap is growing for the North East, North West, Yorkshire and Humberside, East of England, the South West, Wales and Northern Ireland. The gap for the Midlands and Scotland has reduced slightly as their productivity has increased since the financial crisis.

Table 2: Timeline of Turning Points in the Recession for Real GVA, Jobs and Productivity

\begin{tabular}{|c|c|c|c|c|c|c|c|}
\hline Measure & 2006 & 2007 & 2008 & 2009 & 2010 & 2011 & 2012 \\
\hline Peak GVA & & $\begin{array}{l}\text { UK, NE, } \\
\text { NW, YH, } \\
\text { EM, WM, } \\
\text { ET, WL, NI }\end{array}$ & $\begin{array}{c}\mathrm{LN}, \mathrm{SE}, \mathrm{SW}, \\
\text { SC }\end{array}$ & & & & \\
\hline Trough GVA & & & & $\begin{array}{c}\text { UK, NE, } \\
\text { NW, YH, } \\
\text { EM, WM, } \\
\text { ET, LN, SE, } \\
\text { SW, WL, SC }\end{array}$ & $\mathrm{NI}$ & & \\
\hline Peak Jobs & & EM & $\begin{array}{l}\text { UK, NE, NW, } \\
\text { YH, WM, ET, } \\
\text { LN, SE, SW, } \\
\text { WL, SC, NI }\end{array}$ & & & & \\
\hline Trough Jobs & & & & $\begin{array}{c}\text { UK, EM, SE, } \\
\text { SW, WL, }\end{array}$ & $\begin{array}{c}\text { YH, WM, } \\
\text { ET, LN, } \\
\text { SC }\end{array}$ & $\begin{array}{l}\text { NW, } \\
\text { WL }\end{array}$ & $\begin{array}{l}\mathrm{NE}, \\
\mathrm{NI}\end{array}$ \\
\hline $\begin{array}{l}\text { Peak } \\
\text { Productivity }\end{array}$ & $\begin{array}{c}\text { SW, } \\
\mathrm{NI}\end{array}$ & $\begin{array}{c}\text { UK, NW, } \\
\text { YH, WM ET, } \\
\text { LN, WL, SC }\end{array}$ & EM, SE & & & & \\
\hline $\begin{array}{l}\text { Trough } \\
\text { Productivity }\end{array}$ & & & SC & $\begin{array}{c}\text { UK, NE, } \\
\text { NW, YH, } \\
\text { EM, WM, } \\
\text { ET, LN, SE, } \\
\text { SW, WL }\end{array}$ & $\mathrm{NI}$ & & \\
\hline
\end{tabular}


Figure 2: Business Cycle Turning Points for UK and Yorkshire \& Humberside

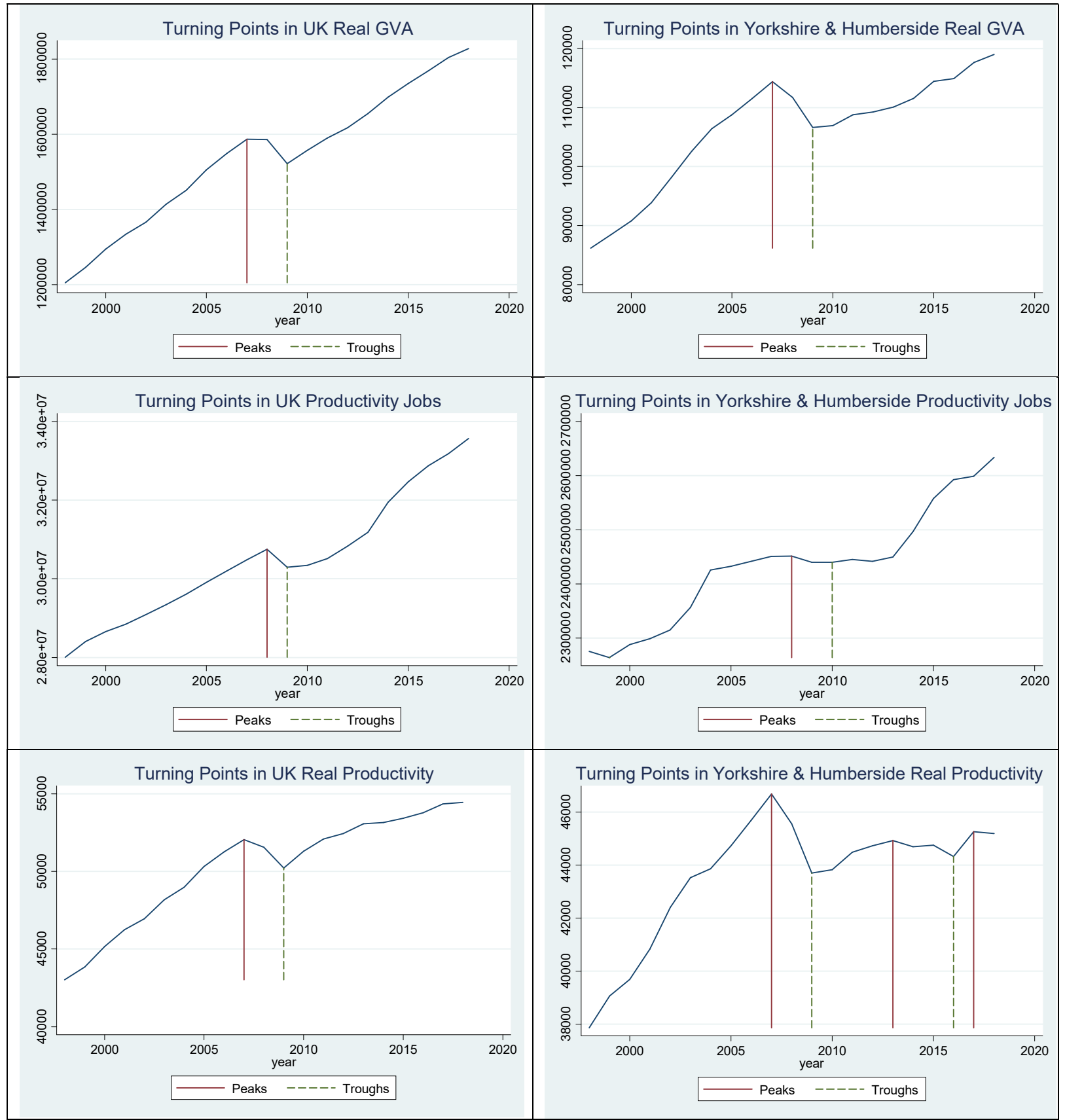

Note: UK real GVA is excluding Extra Regio (in millions of pounds and 2016 prices) and productivity is $f$ per job filled.

The dates of the turning points for each region are shown in Table 2. Here we can see that UK GVA peaks in 2007 with the majority of NUTS 1 areas starting the recession in 2008. London (LN), the South East (SE), South West (SW) and Scotland (SC) lag the national turning point by one year and start the recession in 2009 exiting recession in 2010 after the trough turning point in 2009 along with most other regions. Northern Ireland ( $\mathrm{NI}$ ) is the last to exit recession after its trough turning point in 2010 so has the longest recession duration of 3 
years. The employment series generally peaks a year later than GVA in 2008 for most areas apart from the East Midlands (EM) which is first to reach its peak turning point in 2007. The North East (NE) and Northern Ireland experience the longest downturn in employment of 4 years exiting recession after the trough turning point in 2012. Most regions reach peak productivity turning points in 2007 with SW and $\mathrm{NI}$ reaching it one year earlier in 2006. EM, SE and Scotland only experience one year of decline in productivity and the longest recession of 4 years is experienced by Northern Ireland.

Table 3: Real GVA Real BC Turning Points and Resilience Measures NUTS 1 regions

\begin{tabular}{|l|c|c|c|c|c|c|c|}
\hline Region & $\begin{array}{c}\text { Peak } \\
\text { year }\end{array}$ & $\begin{array}{c}\text { Trough } \\
\text { year }\end{array}$ & $\begin{array}{c}\text { Loss } \\
\text { Peak to } \\
\text { Trough }\end{array}$ & $\begin{array}{c}\text { Beta - } \\
\text { Resist }\end{array}$ & $\begin{array}{c}\text { Year } \\
\text { Recover }\end{array}$ & EAGR & E2AGR \\
\hline UK & 2007 & 2009 & -4.1 & 1 & 2011 & 2.99 & 2.2 \\
\hline NE & 2007 & 2009 & -3.69 & $\mathbf{0 . 9}$ & 2015 & 2.9 & 0.59 \\
\hline NW & 2007 & 2009 & -3.61 & $\mathbf{0 . 8 8}$ & 2014 & 3.02 & 1.44 \\
\hline YH & 2007 & 2009 & -6.78 & 1.66 & 2015 & 3.06 & 0.9 \\
\hline EM & 2007 & 2009 & -5.01 & 1.22 & 2011 & 2.89 & 2.24 \\
\hline WM & 2007 & 2009 & -6.28 & 1.53 & 2011 & 1.74 & $\mathbf{2 . 5 4}$ \\
\hline ET & 2007 & 2009 & -4.32 & 1.05 & 2013 & 2.55 & 1.73 \\
\hline LN & 2008 & 2009 & -5.54 & 1.33 & 2011 & 3.95 & 3.57 \\
\hline SE & 2008 & 2009 & -3.56 & $\mathbf{0 . 8 7}$ & 2011 & 1.95 & $\mathbf{2 . 1 5}$ \\
\hline SW & 2008 & 2009 & -2.7 & $\mathbf{0 . 6 6}$ & 2010 & 1.66 & $\mathbf{2 . 0 1}$ \\
\hline WL & 2007 & 2009 & -5.54 & 1.35 & 2012 & 2.56 & 1.71 \\
\hline SC & 2008 & 2009 & -2.35 & $\mathbf{0 . 5 7}$ & 2011 & 2.51 & 1.96 \\
\hline NI & 2007 & 2010 & -7.18 & 1.75 & 2015 & 2.97 & 1.95 \\
\hline
\end{tabular}

Note: bold font in Beta - Resistance column signifies the region is more resistant than the nation. Bold font in the second expansion average growth rate (E2AGR) column means that this is greater than the expansion average growth rate (EAGR) before the recession.

Charts of the UK national series are shown in Figure 2 against which we benchmark the regions. Here we can see that GVA sustained a deeper recession $(-4.1 \%)$ than jobs $(-1.5 \%$, also found by Gregg and Wadsworth, 2010, who suggested that employers held onto workers and cut hours and pay rather than make them redundant) both series recovered their pre-recession peak levels after 4 years. Real productivity suffered a $-3.5 \%$ fall and also recovered its peak level after 4 years. We present the turning points and resilience measures for real GVA in Table 3 which shows that the largest GVA loss over the recession was for Northern Ireland at $-7.2 \%$ and recorded the longest recession duration of 3 years. The sensitivity index from equation (4) is noted in the fifth column, this is the regional loss over the recession divided by the UK aggregate GVA loss. We find that the North East, North West, South East, South West and Scotland had lower GVA percentage loss than the 
national series so were more resistant. The SE, SW, London and Scotland also experienced the downturn for one year and they recovered their pre-recession peak GVA level quicker. The northern England regions took longest to recover and Yorkshire and Humberside had a large loss of $-6.8 \%$. The North East experienced further falls in the GVA growth rate after the financial crisis, in particular GVA declined in 2013 and 2016 (see Figure A.1) as also found by Koop, et al (2018).

In the final column in Table 3 we show that the average rate of GVA growth after the recession was higher than before the recession (E2AGR>EAGR) for the West Midlands, South East and South West so for 5 years following the recession these regions moved to a higher growth path. The West Midland's GVA loss of $-6.3 \%$ was over 2 years and Bailey and Berkeley (2014) also document the large rise in unemployment during the recession for the West Midlands and the strong recovery in 2010. They suggest the West Midlands was particularly at risk during the recession due to "long-term underinvestment in infrastructure; an ongoing process of deindustrialization and a wider economic structure reliant on low volume, low growth sectors; a relatively poor business and employment performance in the private sector; a relatively poor education and skills record; relatively poor performance in developing 'knowledge economy' sectors and in R\&D spend; and pockets of high levels of unemployment and worklessness" (p.1802). The West Midlands was less resistant than the UK, but rebounded relatively quickly and experienced higher average growth rates after the recession, possibly helped by the West Midlands Regional Taskforce, see Bailey and Berkeley (2014).

Table 4: Productivity Jobs Business Cycle Turning Points and Resilience Measures

\begin{tabular}{|l|c|c|c|c|c|c|c|}
\hline Region & $\begin{array}{c}\text { Peak } \\
\text { year }\end{array}$ & $\begin{array}{c}\text { Trough } \\
\text { year }\end{array}$ & $\begin{array}{c}\text { Loss } \\
\text { Peak to } \\
\text { Trough }\end{array}$ & $\begin{array}{c}\text { Beta }- \\
\text { Resist }\end{array}$ & $\begin{array}{c}\text { Year } \\
\text { Recover }\end{array}$ & EAGR & E2AGR \\
\hline UK & 2008 & 2009 & -1.49 & 1 & 2012 & 0.94 & $\mathbf{1 . 0 6}$ \\
\hline NE & 2008 & 2012 & -3.53 & 2.37 & 2018 & 1.06 & 0.48 \\
\hline NW & 2008 & 2011 & -0.76 & $\mathbf{0 . 5 1}$ & 2013 & 0.62 & $\mathbf{1 . 1 5}$ \\
\hline YH & 2008 & 2010 & -0.48 & $\mathbf{0 . 3 2}$ & 2014 & 0.79 & $\mathbf{0 . 9 4}$ \\
\hline EM & 2007 & 2009 & -2.9 & 1.95 & 2011 & 1.71 & 0.92 \\
\hline WM & 2008 & 2010 & -3.24 & 2.18 & 2013 & 0.54 & $\mathbf{1 . 4 3}$ \\
\hline ET & 2008 & 2010 & -1.61 & 1.08 & 2012 & 0.98 & $\mathbf{1 . 6 3}$ \\
\hline LN & 2008 & 2010 & -1.62 & 1.09 & 2011 & 1.27 & $\mathbf{2 . 8 4}$ \\
\hline SE & 2008 & 2009 & -1.67 & 1.12 & 2011 & 0.65 & $\mathbf{1 . 2 9}$ \\
\hline SW & 2008 & 2009 & -0.13 & $\mathbf{0 . 0 9}$ & 2010 & 1.09 & 1.03 \\
\hline WL & 2008 & 2011 & -1.24 & $\mathbf{0 . 8 4}$ & 2014 & 0.99 & $\mathbf{1 . 1 9}$ \\
\hline SC & 2008 & 2010 & -5.14 & 3.46 & NR & 1.07 & 0.77 \\
\hline NI & 2008 & 2012 & -5.94 & 4 & 2017 & 1.32 & $\mathbf{1 . 4 5}$ \\
\hline
\end{tabular}


In Table 4 the employment turning points and resilience statistics are shown. Northern Ireland suffered the greatest share of jobs lost at $-5.9 \%$ and suffered the longest recession duration of 4 years (along with the North East). Dawley et al. (2014) discuss North East employment in relation to the rise and fall of the Northern Rock bank, in particular they suggest historical occupational disadvantage limited the adaptive capacity and ability of the region to diversify into new growth paths or upgrade economic activities and employment after the crisis, this is evident in the low growth rate in jobs for 5 years after the crisis with a further contraction in employment in 2016. Northern Ireland, the North West and Wales all experienced a "double dip" recession where jobs grew slightly after the first year but fell to a lower level until the trough turning points. The first region to recover its jobs pre-recession peak level in 2010 was the South West and the longest is Scotland which had still not recovered its pre-recession peak jobs level by 2018. Jobs growth was greater after the recession than before for the UK, and for most regions apart from the North East, East Midlands, South West and Scotland where jobs growth slowed. Figure A.3 shows the time series for London which had the highest rate of growth of jobs after the recession as also reported by Beatty and Fothergill (2018). Overman (2011) suggested the larger proportion of middle income earners and jobs in the professional services helped London recover quicker, along with the Government's bank bailouts protecting jobs in the finance sector. Infrastructure investment in the construction of Olympics venues and Crossrail also helped. Coyle and Sensier (2020) highlight how London had the highest concentration of transport infrastructure spending $(£ 3,200$ per head between 2013-2017) compared to the next highest region the North West ( $£ 1,300$ per head).

Table 5: Real Productivity Business Cycle Turning Points and Resilience Measures

\begin{tabular}{|l|c|c|c|c|c|c|c|}
\hline Region & $\begin{array}{c}\text { Peak } \\
\text { year }\end{array}$ & $\begin{array}{c}\text { Trough } \\
\text { year }\end{array}$ & $\begin{array}{c}\text { Loss } \\
\text { Peak to } \\
\text { Trough }\end{array}$ & $\begin{array}{c}\text { Beta }- \\
\text { Resist }\end{array}$ & $\begin{array}{c}\text { Year } \\
\text { Recover }\end{array}$ & EAGR & E2AGR \\
\hline UK & 2007 & 2009 & -3.51 & 1 & 2011 & 2.06 & 1.13 \\
\hline NE & 2007 & 2009 & -3.63 & 1.03 & 2011 & 1.52 & 1.04 \\
\hline NW & 2007 & 2009 & -3.31 & $\mathbf{0 . 9 4}$ & 2013 & 2.27 & 0.66 \\
\hline YH & 2007 & 2009 & -6.11 & 1.74 & NR & 1.92 & 0.45 \\
\hline EM & 2008 & 2009 & -2.85 & $\mathbf{0 . 8 1}$ & 2012 & 0.96 & $\mathbf{1 . 3 2}$ \\
\hline WM & 2007 & 2009 & -3.96 & 1.13 & 2010 & 1.10 & $\mathbf{1 . 6 5}$ \\
\hline ET & 2007 & 2009 & -3.25 & $\mathbf{0 . 9 2}$ & 2016 & 1.48 & 0.5 \\
\hline LN & 2007 & 2009 & -6.44 & 1.83 & 2016 & 3.91 & 1.14 \\
\hline SE & 2008 & 2009 & -1.92 & $\mathbf{0 . 5 5}$ & 2011 & 1.3 & 0.86 \\
\hline SW & 2006 & 2009 & -3.48 & $\mathbf{0 . 9 9}$ & 2012 & 1.13 & 0.98 \\
\hline WL & 2007 & 2009 & -5.37 & 1.53 & 2011 & 1.28 & 0.97 \\
\hline SC & 2007 & 2008 & -0.26 & $\mathbf{0 . 0 7}$ & 2009 & 1.97 & 1.78 \\
\hline NI & 2006 & 2010 & -6.98 & 1.99 & 2012 & 1.61 & $\mathbf{1 . 9 9}$ \\
\hline
\end{tabular}


In Table 5 we see that Northern Ireland experienced the greatest decline in productivity (7\%) over 4 years of recession but it recovered by 2012 and had a faster average productivity growth rate after the recession (E2AGR). Yorkshire and Humberside's productivity fell by $6.1 \%$ over the downturn and was yet to recover by 2018 , see Figure 2 . The combination of a large fall in GVA and shallow loss of employment $(-0.5 \%)$ over the recession followed by a rapid jobs recovery from 2013 meant productivity was reduced markedly with jobs growing faster than GVA keeping productivity growth flat. Figure A.2 presents the business cycle turning points for the East and West Midlands, both experienced higher productivity growth after the recession meaning that the series are on a higher growth path. The rapid job growth in London appeared to dampen the recovery in productivity as real GVA did not rise as quickly, so for the five years after the recession the average productivity growth rate was $1.1 \%$ compared to the average of $3.9 \%$ for the five years before (see Figure A.3). The prerecession productivity peak level recovered by 2016 for London but experienced a small downturn in 2017 recovering by 2018.

Table 6: Resilience Scorecard for NUTS 1 regions

\begin{tabular}{|l|l|l|l|l|l|l|l|l|l|l|l|l|}
\hline & NE & NW & YH & EM & WM & ET & LN & SE & SW & WL & SC & NI \\
\hline GVA & & & & & & & & & & & & \\
\hline 1 & 1 & 1 & 0 & 0 & 0 & 0 & 0 & 1 & 1 & 0 & 1 & 0 \\
\hline 2 & 1 & 1 & 1 & 1 & 1 & 1 & 1 & 1 & 1 & 1 & 1 & 0 \\
\hline 3 & 0 & 0 & 0 & 1 & 1 & 0 & 1 & 1 & 1 & 0 & 1 & 0 \\
\hline 4 & 0 & 0 & 0 & 0 & 1 & 0 & 0 & 1 & 1 & 0 & 0 & 0 \\
\hline Jobs & & & & & & & & & & & & \\
\hline 1 & 0 & 1 & 1 & 0 & 0 & 0 & 0 & 0 & 1 & 1 & 0 & 0 \\
\hline 2 & 0 & 0 & 0 & 0 & 0 & 0 & 0 & 1 & 1 & 0 & 0 & 0 \\
\hline 3 & 0 & 0 & 0 & 1 & 0 & 1 & 1 & 1 & 1 & 0 & 0 & 0 \\
\hline 4 & 0 & 1 & 1 & 0 & 1 & 1 & 1 & 1 & 0 & 1 & 0 & 1 \\
\hline Prod & & & & & & & & & & & & \\
\hline 1 & 0 & 1 & 0 & 1 & 0 & 1 & 0 & 1 & 1 & 0 & 1 & 0 \\
\hline 2 & 1 & 1 & 1 & 1 & 1 & 1 & 1 & 1 & 0 & 1 & 1 & 0 \\
\hline 3 & 1 & 0 & 0 & 1 & 1 & 0 & 0 & 1 & 0 & 1 & 1 & 0 \\
\hline 4 & 0 & 0 & 0 & 1 & 1 & 0 & 0 & 0 & 0 & 0 & 0 & 1 \\
\hline Total & 4 & 6 & 4 & 7 & 7 & 5 & 5 & 10 & 8 & 5 & 6 & 2 \\
\hline Rank & 6 & 4 & 6 & 3 & 3 & 5 & 5 & 1 & 2 & 5 & 4 & 7 \\
\hline
\end{tabular}

Key: 1 - RESISTANCE; 2 - DURATION; 3 - RECOVERY and 4 - RENEWAL.

The summary of the resilience scorecard for NUTS 1 regions is in Table 6 . The NUTS 1 ranking of resilience shows that the most resilient region was the South East and the least resilient region was Northern Ireland. The South West also scores highly, then the Midlands, North West and Scotland score higher than London, the East of England, Wales and 
Yorkshire and Humberside. When we analyse the sub-regions at the NUTS 2 level in Sensier and Devine (2019) what emerges is that South East and South West regions are still the most resilient, but within the South West the Bristol region was the most resilient with other sub-regions (Dorset, Devon and Cornwall) performing poorly on GVA and productivity indicators so they are lower down in the scorecard. When the components of the Midlands are scored by sub-regions Lincolnshire scores highly, followed by Derbyshire and Nottingham but the Birmingham city region does less well along with Leicestershire, Rutland and Northamptonshire. Greater Manchester scored the same as the region it is within (the North West) as it has had strong employment growth but subdued productivity growth, not yet recovering its pre-recession peak level. So looking beyond the headline figures for the nation and the main regions we find quite different levels of resilience at sub-regional levels.

\section{Conclusions}

To understand a region's economic resilience we first dated the business cycle turning points so we could determine when the region was experiencing recession, how it recovered and then compared the recovery growth rate to the rate of growth before the onset of the global financial crisis. By quantifying expansion gains and recessions losses for the economic resilience dimensions of resistance, recovery and renewal between the peak and trough turning points of the cycle we created a resilience scorecard to rank the effect of the crisis on UK NUTS 1 regions. Most UK region's real productivity series have returned to their pre-recession levels but rapid job growth in most regions (apart from the North East and Scotland) has reduced productivity growth rates, possibly due to the growth of low paid employment and the "hollowing out" of middle earning jobs which are easier to automate (Goos and Manning, 2007). Our findings show that the English regions of the South East, South West and the Midlands rank highest in the resilience scorecard but when looking at sub-regions within these we find some regions are not doing as well. Our resilience scorecard could be useful for national policy makers to help identify the UK regions that have lacked economic resilience during and since the downturn in an aim to level up resources for these areas to increase resilience in preparation for future downturns. The scorecard could also be useful for local areas that are producing local industrial strategies and need to understand the resilience of sub-regions within localities. The factors affecting resilience could be explored further in future work and could help direct future funding streams (like the Shared Prosperity Fund) towards the regions lacking economic resilience to help reduce regional disparities. 


\section{References}

Bailey, D. and Berkeley, N. (2014) Regional Responses to Recession: The Role of the West Midlands Regional Taskforce, Regional Studies, 48:11, 1797-1812. DOI: 10.1080/00343404.2014.893056

Beatty, C. and Fothergill, S. (2018) The Contemporary Labour Market in Britain's Older Industrial Towns, Centre for Regional Economic and Social Research (Sheffield Hallam University), available at: http://shura.shu.ac.uk/22129/.

Bristow, G. and Healy, A. (2014) Regional resilience: an agency perspective, Regional Studies, 48, 923-935.

Coyle, D. (2018) Do-it-yourself Digital: the Production Boundary, the Productivity Puzzle and Economic Welfare, Economica, doi:10.1111/ecca.12289

Coyle, D. and Sensier, M. (2020). The Imperial Treasury: appraisal methodology and regional economic performance in the UK, Regional Studies, 54:3, 283-295, https://doi.org/10.1080/00343404.2019.1606419.

Dawley, N.M., Pike, A. Pollard, J. and Tomaney, J. (2014) Continuity and Evolution in an Old Industrial Region: The Labour Market Dynamics of the Rise and Fall of Northern Rock, Regional Studies, 48:1, 154-172, DOI: 10.1080/00343404.2012.669473

Forth, J and Aznar, A.R. (2018) Productivity in the UK's low-wage sectors, Joseph Rowntree Foundation research report, from: https://www.jrf.org.uk/report/links-between-lowproductivity-low-pay-and-work-poverty

Goos, M., Manning, A. (2007) Lousy and lovely jobs: the rising polarization of work in Britain, Review of Economics and Statistics, 89: no.1, 118-133.

Gregg, P. and Wadsworth, J. (2010) Employment in the 2008-9 recession, Economic and Labour Market Review, 4: 437-456.

Han, Y. and Goetz, S.J. (2015) The Economic Resilience of U.S. Counties during the Great Recession, The Review of Regional Studies, 45: 131-149.

Harding D. and Pagan A. (2002) Dissecting the cycle: a methodological investigation, Journal of Monetary Economics, 49: 365-381.

Industrial Strategy Commission (2017). The Final Report of the Industrial Strategy Commission, November 2017. Download from: http://industrialstrategycommission.org.uk/

Kitsos, A. and Bishop, P. (2018) Economic resilience in Great Britain: the crisis impact and its determining factors for local authority districts, The Annals of Regional Science, 60:2, 329347. 
Koop, G., McIntyre, S., Mitchell, J. and Poon, A. (2018) Regional Output Growth in the United Kingdom: More Timely and Higher Frequency Estimates, 1970-2017, ESCoE Discussion Paper 2018-14.

Lee, N. (2014) Grim down South? The Determinants of Unemployment Increases in British Cities in the 2008-2009 Recession, Regional Studies, 48:11, 1761-1778.

Lewin, P.A., Watson, P. and Brown, A. (2018) Surviving the Great Recession: the influence of income inequality in US urban counties, Regional Studies, 52: 6, 781-792. DOI: 10.1080/00343404.2017.1305492

Manca, A.R., Benczur, P. and Giovannini, E. (2017) Building a Scientific Narrative Towards a More Resilient EU Society: Part 1: a Conceptual Framework, JRC Science for Policy Report. Downloaded $13 / 12 / 18$ from: http://publications.jrc.ec.europa.eu/repository/bitstream/JRC106265/irc106265 100417 r esilience scienceforpolicyreport.pdf

Martin, R.L. (2012) Regional Economic Resilience, Hysteresis and Recessionary Shocks, Journal of Economic Geography, 12:1, 1-32.

Martin, R.L. and Sunley, P. (2015) On the notion of regional economic resilience: conceptualisation and explanation, Journal of Economic Geography, 15:1, 1-42. DOI:10.1093/jeg/lbu015

Martin, R.L., Sunley, P., Gardiner, B. and Tyler, P. (2016) How Regions React to Recessions: Resilience and the Role of Economic Structure, Regional Studies, 50:4, 561-585. DOI: 10.1080/00343404.2015.1136410

Martin, R.L. and Gardiner, B. (2019) The Resilience of Cities to Economic Shocks: A Tale of Four Recessions (and the Challenge of Brexit), Papers in Regional Science, 98:4, 1801-32. https://doi.org/10.1111/pirs.12430.

McCann, P. (2018) Productivity Perspectives Synthesis, Productivity Insights Network - 07, https://productivityinsightsnetwork.co.uk/app/uploads/2018/11/Productivity-PerspectivesSynthesis-updated-21.11.18.pdf, Evidence Review.

ONS (2020). Region by industry labour productivity: 5 February 2020 https://www.ons.gov.uk/economy/economicoutputandproductivity/productivitymeasures/ datasets/industrybyregionlabourproductivity

Overman, H. (2011) How did London get away with it? CentrePiece Winter 2010/11, web: http://cep.Ise.ac.uk/pubs/download/cp333.pdf (retrieved 27/6/19).

Pontarollo, N. and Serpieri, C. (2018) A composite policy tool to measure territorial resilience capacity, Socio-economic Planning Sciences. 
Ringwood, L., Watson, P. and Lewin, P.A. (2019) A quantitative method for measuring regional economic resilience to the great recession, Growth and Change, 50, no. 1: 381-402.

Sensier, M. and Artis M.J. (2016) The Resilience of Employment in Wales: Through Recession and into Recovery, Regional Studies, 50:4, 586-599. DOI: 10.1080/00343404.2014.920083

Sensier, M., Bristow, G. and Healy, A. (2016) Measuring Regional Economic Resilience across Europe: Operationalising a complex concept, Spatial Economic Analysis, 11:2, 128-151.

Sensier, M. and Devine, F. (2019). "Understanding regional economic performance and resilience in the UK: trends since the Global Financial Crisis", University of Manchester Economics Discussion Paper no. 12, download from http://hummedia.manchester.ac.uk/schools/soss/economics/discussionpapers/EDP1912.pdf

Sichel, D.E. (2019) Productivity Measurement: Racing to Keep Up, NBER Working Paper No. 25558.

Wong, C., Arnold, T., Baker, M, Koksal, C., Schulze Bäing A. and Wei Zheng, H. (2019) Measuring Spatial Inequality in the UK: What We Know and What We Should Know? The Spatial Policy \& Analysis Laboratory, Manchester Urban Institute, University of Manchester, UK 2070 Commission Evidence. Downloaded from: http://uk2070.org.uk/publications/ 
Appendix: UK NUTS 1 regions and countries Business Cycle Turning points in Real GVA, Jobs and Real Productivity

Figure A.1: North East and North West

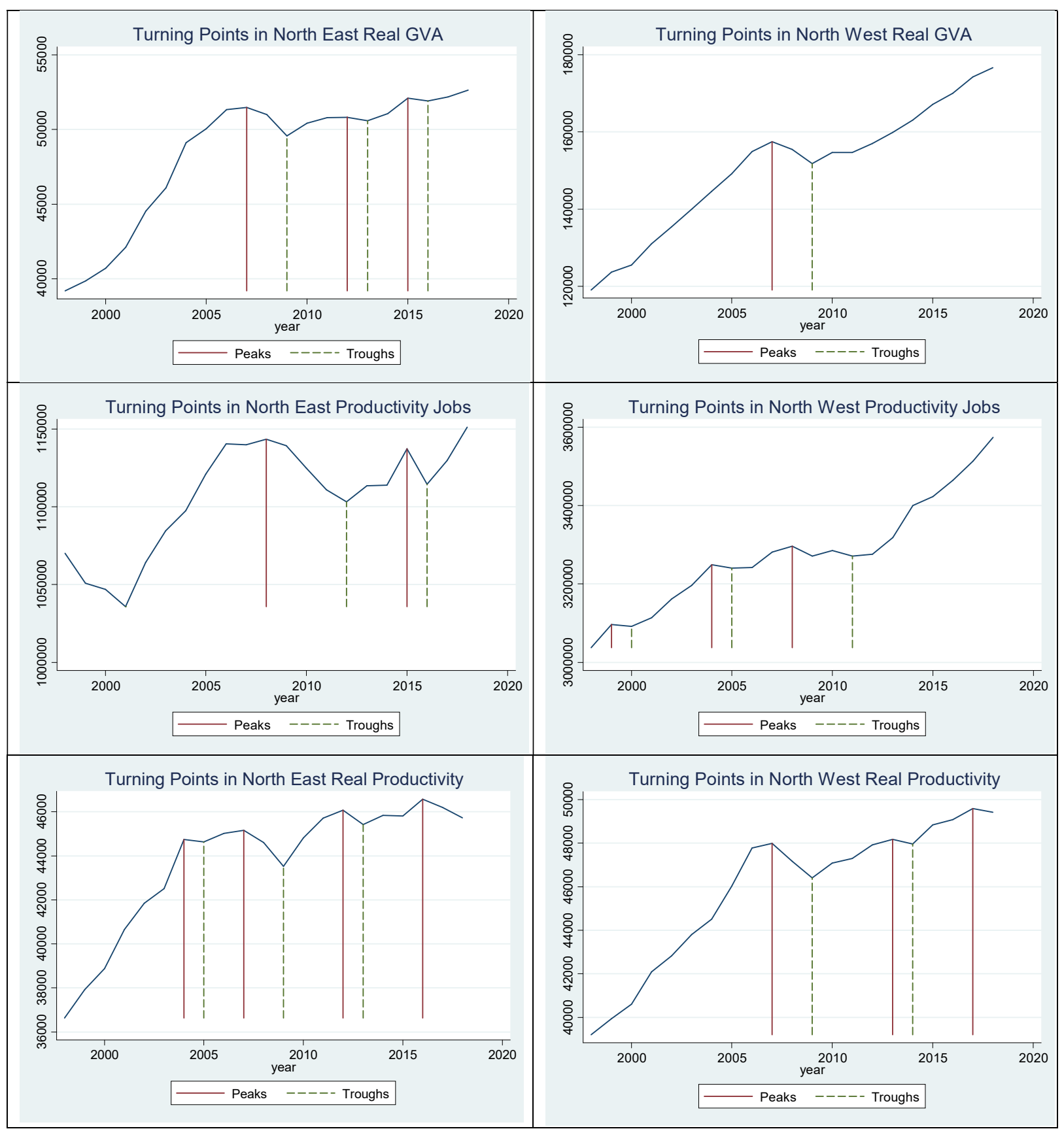


Figure A.2: East and West Midlands

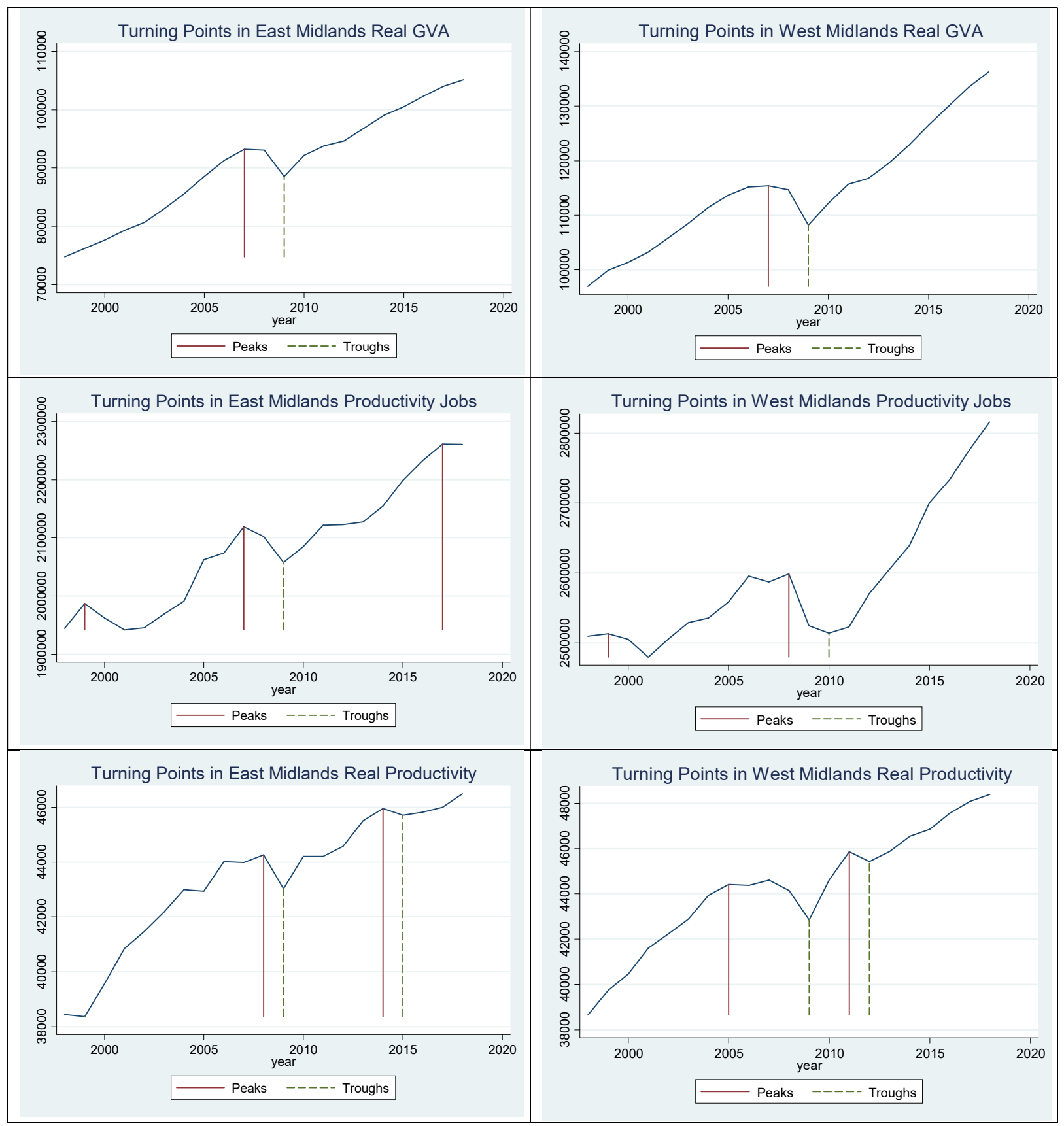


Figure A.3: East of England and London

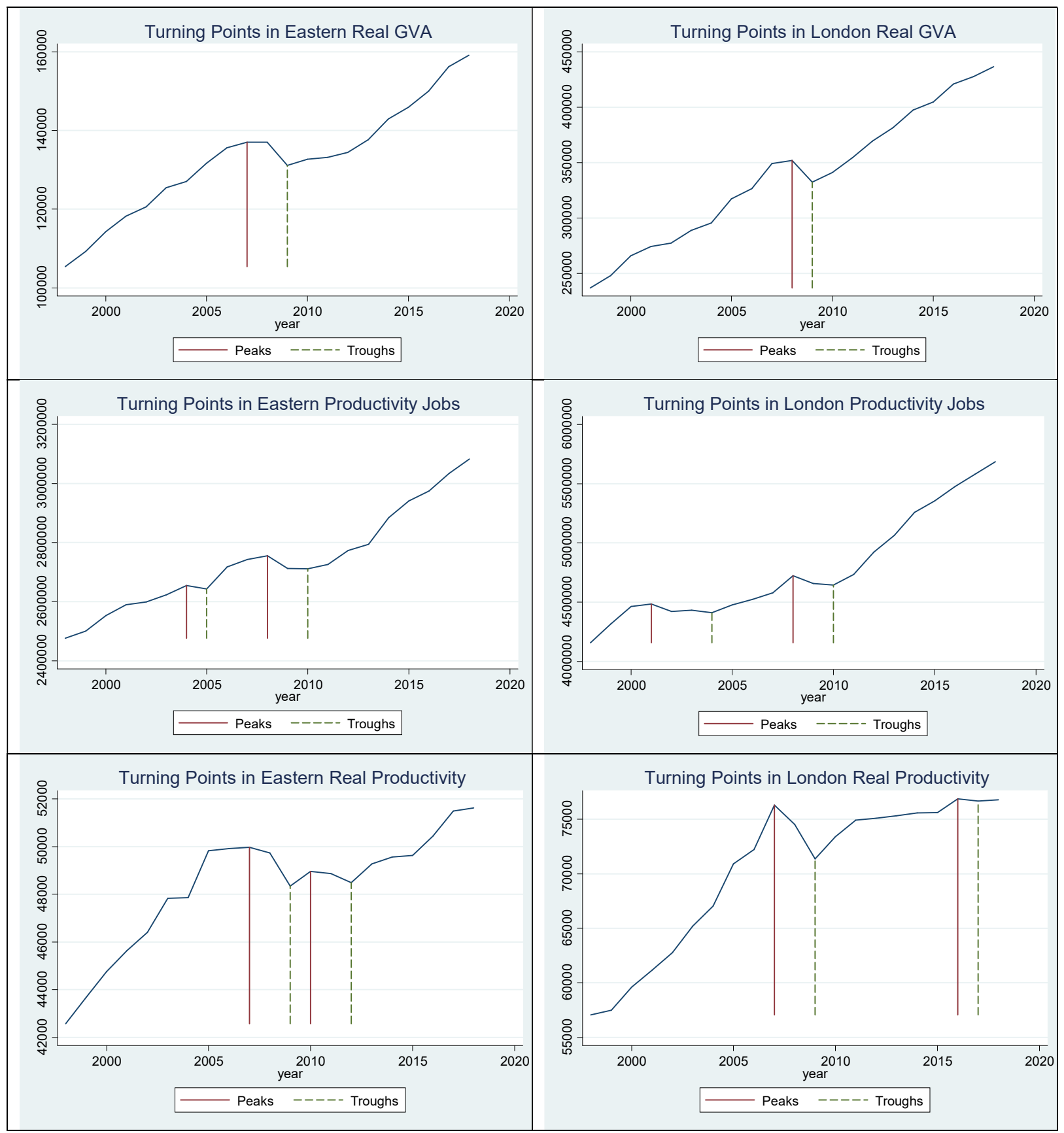


Figure A.4: South East and South West

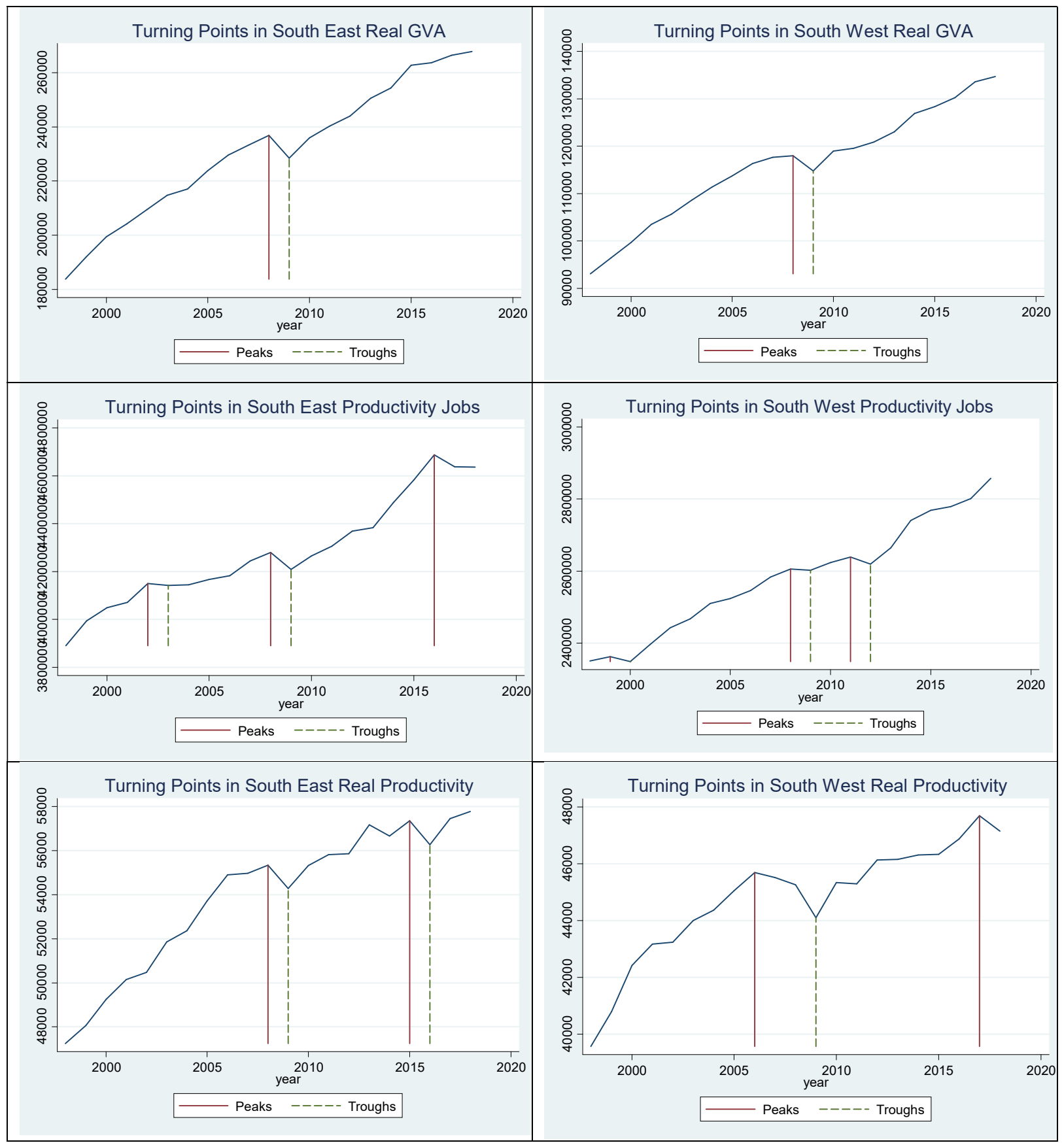


Figure A.5: Wales and Scotland

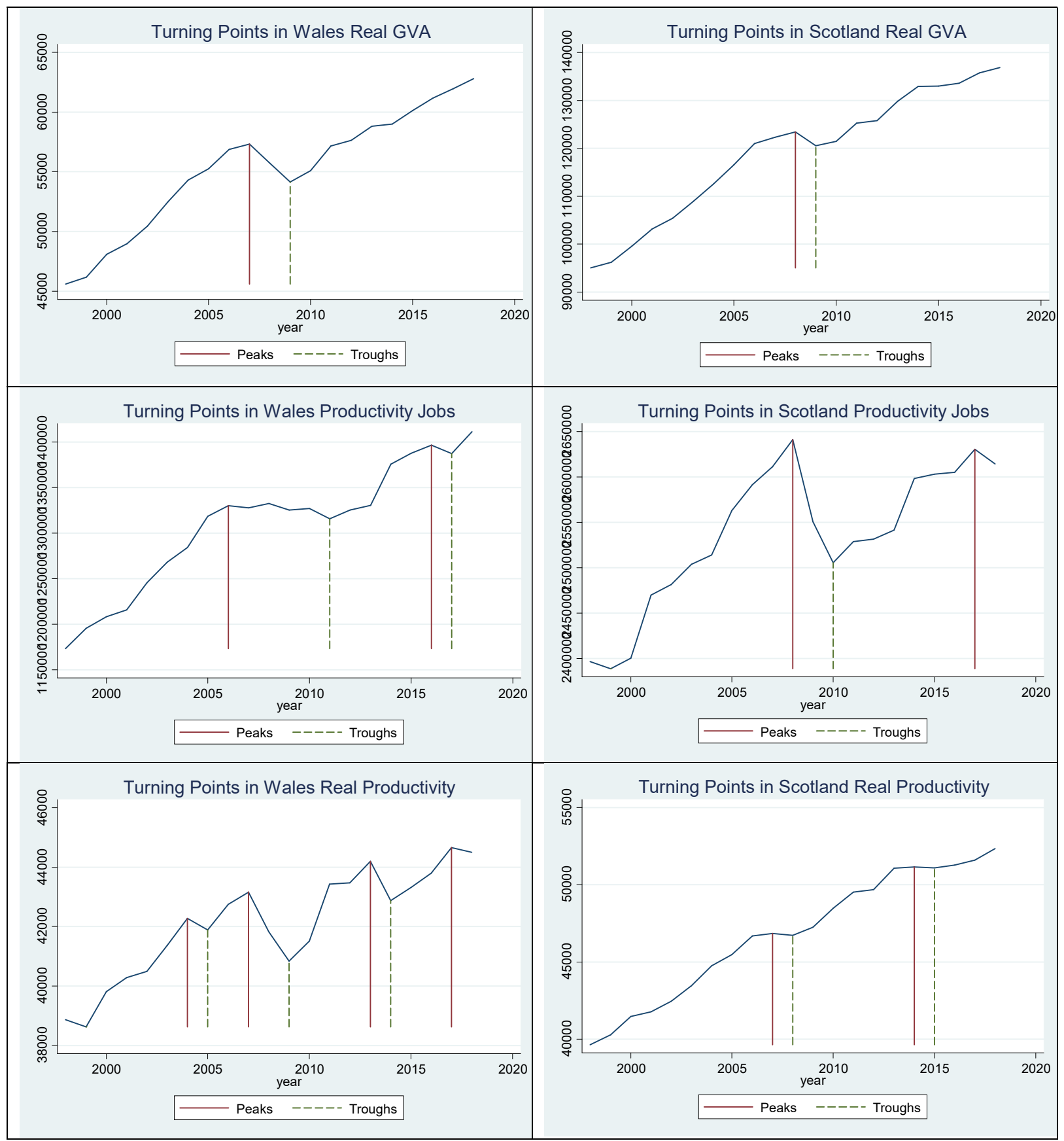


Figure A.6: Northern Ireland

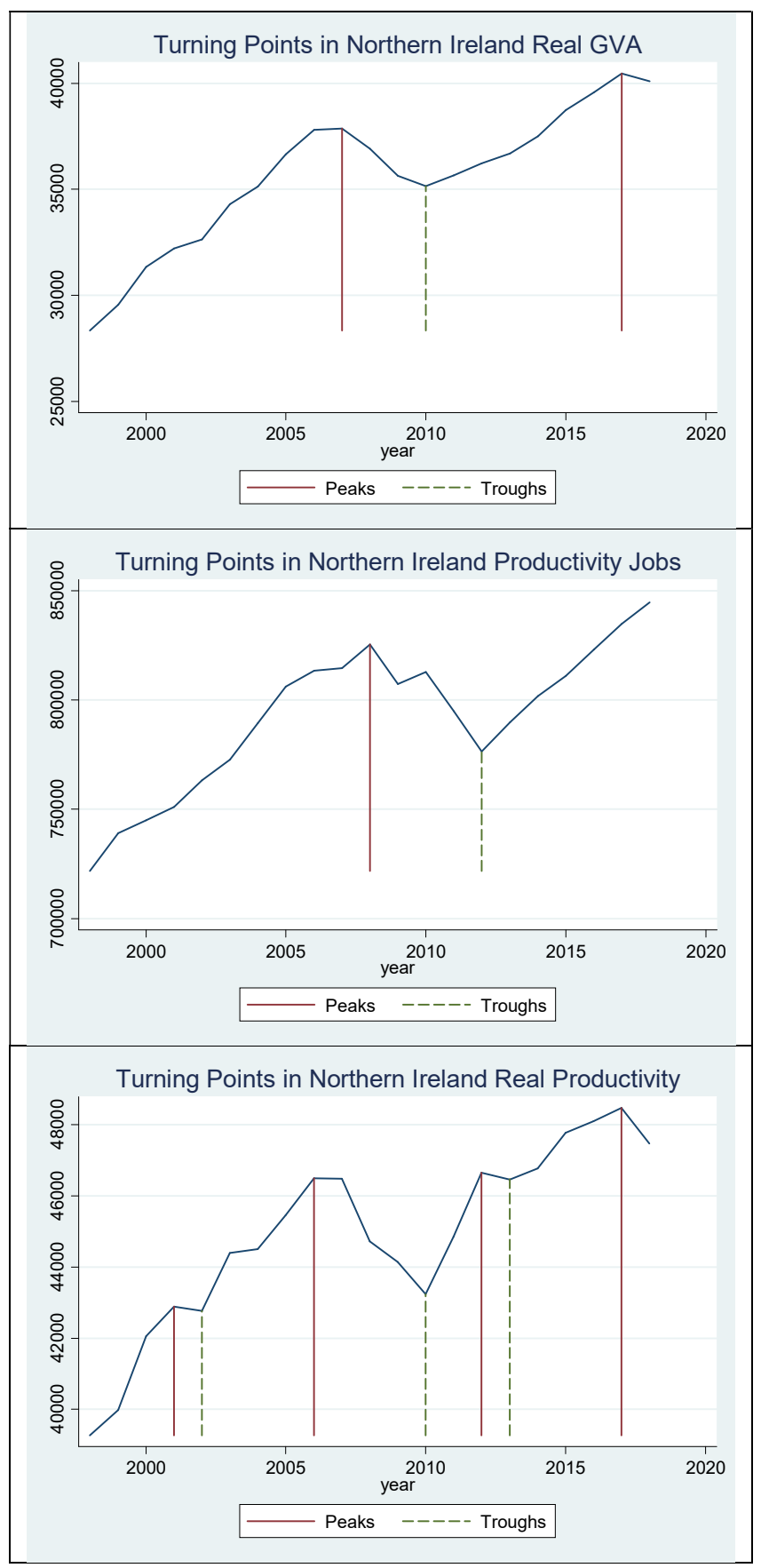

